\title{
ANTIBIOTIC-RESISTANT GRAM-NEGATIVE BACILLI IN THE FAECES OF NEONATES
}

\author{
Judith H. Noy*, G. A. J. Ayliffe* and K. B. Linton $\dagger$ \\ ${ }^{*}$ Hospital Infection Research Laboratory, Summerfield Hospital, Birmingham 18, \\ and $\dagger$ Department of Bacteriology, University of Bristol
}

Antibiotic-RESISTANT Gram-negative bacilli commonly occur in the faeces of normal adults and infants (see, for example, Datta, 1969; Moorhouse, 1969; Linton et al., 1972). These strains may be acquired from food (Shooter et al., 1971) or as a result of cross-infection from infected patients or healthy carriers. Contaminated meat may be an important source (Anderson 1965, 1968b). It seems likely that neonates acquire antibiotic-resistant Gramnegative bacilli from their mothers during delivery. Resistant strains detected in the facices may also be acquired from infant feeds (Ayliffe, Collins and Pettit, 1970) and by cross-infection in the nursery. In the present study, the acquisition of resistant Gram-negative bacilli and the frequency of transferable resistance in these strains has been investigated in neonates born in hospital. Surveys were made of faeces of infants in general maternity wards and Special Care Units of three hospitals in the Birmingham area. In the Bristol Maternity Hospital, daily samples of faeces from individual babies were examined to determine the time of acquisition of resistant Gram-negative bacilli; faeces samples from mothers were also examined.

\section{MATERIALS AND METHODS}

\section{Source of samples}

Faeces. A series of surveys was made in the Birmingham hospitals (A, B, C) in which samples of faeces were collected from each infant present in a ward or unit on one day. Samples were also obtained from a few mothers. Daily samples of faeces were collected from each baby in the Bristol hospital D until the baby was discharged from hospital. A sample of faeces or of enema fluid was also obtained from mothers in hospital D soon after admission and before delivery. Where possible, faeces were again obtained from the mothers about 1 week after delivery. The dates and types of delivery and details of any antibiotics given to mothers and babies were recorded.

Other samples were taken from a number of sites, e.g., incubators, sinks, creams, baths suction equipment and soaps in Hospital $A$ on several occasions; and 83 samples of infant feeds from Hospitals A, B and C were examined bacteriologically. Samples other than faeces were cultured on blood agar and MacConkey medium and in nutrient broth. Subcultures were made from the nutrient broth to the modified cetrimide medium after incubation for 18 hours.

\section{Bacteriology}

Swabs of faeces were spread evenly over the surface of one MacConkey plate. An antibiotic ring or individual disks ("Mast") containing the following antibacterial agents were applied to the plate: streptomycin $(25 \mu \mathrm{g})$, tetracycline $(100 \mu \mathrm{g})$, ampicillin $(25 \mu \mathrm{g})$,

Received 24 Jan. 1974; accepted 25 Apr. 1974.

J. MED. MICROBIOL.-VOL. 7 (1974) 
chloramphenicol $(50 \mu \mathrm{g})$, nalidixic acid $(30 \mu \mathrm{g})$, nitrofurantoin $(200 \mu \mathrm{g})$, colistin $(200 \mu \mathrm{g})$, kanamycin $(30 \mu \mathrm{g})$, carbenicillin $(100 \mu \mathrm{g})$, gentamicin $(10 \mu \mathrm{g})$ and cephaloridine $(25 \mu \mathrm{g})$. A second MacConkey plate was seeded from the swab to obtain individual colonies, and the swab was then transferred to nutrient broth. Plates and broths were incubated for 18 hours at $37^{\circ} \mathrm{C}$. Organisms growing adjacent to antibiotic disks were subcultured and transferred to agar slopes for further tests. Broth cultures were subcultured to a modified cetrimide agar (Brown and Lowbury, 1965) for isolation of Pseudomonas aeruginosa. Gram-negative bacilli were identified by the methods of Cowan and Steel (1965) and, apart from Escherichia coli and $P$ s. aeruginosa, are reported according to their genera. Sensitivity tests with the same antibiotics were repeated for all strains of $E$. coli and Klebsiella spp. subcultured from the primary plates; for these sensitivity tests, plates of Oxoid DST Medium were flood-seeded with a broth culture diluted 1 in 500 and the plates were dried. Resistant $E$. coli isolates were further tested for sensitivity to sulphonamide with a sulphadiazine $(200 \mu \mathrm{g})$ disk on the Oxoid medium containing lysed blood. After incubation for 18 hours at $37^{\circ} \mathrm{C}$, zone sizes (mean diameters) were compared with those obtained with a standard sensitive strain of $E$. coli. Organisms giving reduced zone sizes $(2 \mathrm{~mm}$ less than control) were classified as resistant, and strains resistant to at least one of the antibacterial agents used for screening are referred to as " antibiotic-resistant strains" in the text.

Transfer of resistance was tested by the method of Datta (1969) on strains of $E$. coli and Klebsiella spp. with a nalidixic acid-resistant strain of $E$. coli $\mathrm{K} 12$ as a recipient. Klebsiella spp. were typed by a bacteriocine technique modified from that described by Hall (1971). Three membrane filters (Oxoid $4.7 \mathrm{~cm}$, pore size $0.45 \mu \mathrm{m}$ ) were placed on the surface of a 6-in. plate containing MacConkey medium. The membrane filters were inoculated in different areas with a loopful of solid culture of each of the 10 standard bacteriocine-producing strains-nos. $3,4,5,7,23,24,27,30,77$ and 9137 . The plates were incubated at $37^{\circ} \mathrm{C}$ for 18 hours and the membrane filters were removed. A suspension was made from 3-4 colonies of the test strain emulsified in $5 \mathrm{ml}$ of nutrient broth. The MacConkey plates were flooded with the suspension and dried; after incubation at $37^{\circ} \mathrm{C}$ for $6-8$ hours, inhibition of growth was recorded. Control test strains sensitive to all bacteriocines were included in each batch tested. Strains of antibiotic-resistant $E$. coli were tested by slide-agglutination with a polyvalent antiserum against enteropathogenic serotypes of $E$. coli. Agglutination was obtained with one strain only, which was identified with a single antiserum as 086. Some strains of Klebsiella spp. were typed serologically by Dr I. Ørskov.

\section{RESULTS \\ Isolation of antibiotic-resistant Gram-negative bacilli}

Most of the samples isolated from the faeces of neonates yielded a predominant growth of $E$. coli, usually fully sensitive to antibiotics. Other Gramnegative bacilli, especially Klebsiella spp., were sometimes found as the predominant organisms, but were usually present in much smaller numbers. The frequency of isolation of different species of Gram-negative bacilli from samples is shown in table $\mathrm{I}$.

Isolations of Klebsiella spp. were varied, ranging from $6 \%$ in the ordinary wards of Hospital C to $65 \%$ in the Special Care Unit of Hospital B. Gramnegative bacilli other than Escherichia and Klebsiella spp, were less frequently found in all hospitals. No Salmonella spp. or recognised intestinal pathogens other than one enteropathogenic strain of $E$. coli were isolated.

\section{Acquisition of antibiotic-resistant Escherichia coli and Klebsiella spp.}

The data given in detail in table II and summarised in figs. 1-4 show that some resistant strains of $E$. coli and Klebsiella were acquired by babies soon 
after birth. Acquisition of resistant $E$. coli was slower in the special care units than in other wards during the first few days after birth, but increased rapidly after 5-6 days in special care units. The acquisition of Klebsiella spp. rose

TABLE I

Incidence of some Gram-negative bacilli isolated from neonates

\begin{tabular}{|c|c|c|c|c|c|c|c|}
\hline \multirow{2}{*}{$\begin{array}{l}\text { Hospital } \\
\text { and } \\
\text { area* }\end{array}$} & \multirow{2}{*}{$\begin{array}{c}\text { Number of } \\
\text { babies } \\
\text { sampled }\end{array}$} & \multicolumn{5}{|c|}{$\begin{array}{c}\text { Number (and percentage) of babies from whom } \\
\text { the following organisms were isolated }\end{array}$} & \multirow[b]{2}{*}{$\begin{array}{c}\text { Other } \\
\text { Gram-negative } \\
\text { bacilli }\end{array}$} \\
\hline & & $\begin{array}{l}\text { Proteus } \\
\text { spp. }\end{array}$ & $\begin{array}{l}\text { Pseudomonas } \\
\text { aeruginosa }\end{array}$ & $\begin{array}{l}\text { Klebsiella } \\
\text { spp. }\end{array}$ & $\begin{array}{l}\text { Escherichia } \\
\text { coli }\end{array}$ & $\begin{array}{l}\text { Serratia } \\
\text { marcescens }\end{array}$ & \\
\hline $\begin{array}{l}\text { A-SCU } \\
\text { A-wards } \\
\text { B-SCU } \\
\text { B-wards } \\
\text { C-SCU } \\
\text { C--wards } \\
\text { D-wards }\end{array}$ & $\begin{array}{r}214 \\
109 \\
46 \\
70 \\
21 \\
31 \\
93\end{array}$ & $\begin{array}{r}18 \\
6 \\
6 \\
4 \\
5 \\
1 \\
4\end{array}$ & $\begin{array}{l}5 \\
1 \\
1 \\
0 \\
3 \\
1 \\
2\end{array}$ & $\begin{array}{r}122 \\
38 \\
30 \\
16 \\
13 \\
2 \\
14\end{array}$ & $\begin{array}{r}169 \\
79 \\
29 \\
39 \\
13 \\
22 \\
71\end{array}$ & $\begin{array}{l}0 \\
1 \\
0 \\
0 \\
0 \\
2 \\
0\end{array}$ & $\begin{array}{r}9 \\
12 \\
6 \\
9 \\
3 \\
4 \\
17\end{array}$ \\
\hline All & 584 & $44(8)$ & $13(2)$ & $235(40)$ & $422(72)$ & $3(0.5)$ & $60(10)$ \\
\hline
\end{tabular}

* Wards or special care units (SCU) of hospitals in Birmingham (A, B, C) or Bristol (D) were included in the study.

TABLE II

Age of acquisition of resistant Escherichia coli and Klebsiella spp. in neonatal faeces

\begin{tabular}{|c|c|c|c|c|c|c|}
\hline \multirow[b]{2}{*}{$\begin{array}{l}\text { Age } \\
\text { in } \\
\text { days }\end{array}$} & \multicolumn{3}{|c|}{ Data for neonates in special care units } & \multicolumn{3}{|c|}{ Data for neonates in other wards } \\
\hline & $\begin{array}{l}\text { Total } \\
\text { samples } \\
\text { taken }\end{array}$ & $\begin{array}{c}\text { Number of } \\
\text { resistant } \\
E \text {. coli } \\
\text { isolated }\end{array}$ & $\begin{array}{c}\text { Number of } \\
\text { resistant } \\
\text { Klebsiella spp. } \\
\text { isolated }\end{array}$ & $\begin{array}{c}\text { Total } \\
\text { samples } \\
\text { taken }\end{array}$ & $\begin{array}{l}\text { Number of } \\
\text { resistant } \\
E . \text { coli } \\
\text { isolated }\end{array}$ & $\begin{array}{c}\text { Number of } \\
\text { resistant } \\
\text { Klebsiella spp. } \\
\text { isolated }\end{array}$ \\
\hline $\begin{array}{l}1 \\
2 \\
3 \\
4 \\
5-6 \\
7-8 \\
9+\end{array}$ & $\begin{array}{r}10 \\
34 \\
23 \\
14 \\
37 \\
24 \\
139\end{array}$ & $\begin{array}{r}0 \\
4 \\
3 \\
1 \\
12 \\
9 \\
77\end{array}$ & $\begin{array}{r}0 \\
3 \\
7 \\
3 \\
18 \\
15 \\
90\end{array}$ & $\begin{array}{r}141 \\
85 \\
87 \\
74 \\
104 \\
81 \\
35\end{array}$ & $\begin{array}{l}20 \\
22 \\
18 \\
16 \\
25 \\
24 \\
11\end{array}$ & $\begin{array}{r}4 \\
9 \\
15 \\
12 \\
27 \\
21 \\
8\end{array}$ \\
\hline All & 281 & 106 & 136 & 607 & 136 & 96 \\
\hline
\end{tabular}

steadily to over $60 \%$ in special care units, contrasting with the lower rate of acquisition (less than $30 \%$ ) in other wards.

The four hospitals showed marked differences in the proportion of neonates carrying antibiotic-resistant strains. This was partly due to the contribution of the special care baby units, since almost twice as many babies in the Special Care Unit were sampled than in the general wards of Hospital A, whereas no 
babies were sampled in the Special Care Unit of Hospital D (see table I). Approximately $35 \%$ of babies in Hospital A carried antibiotic-resistant $E$. coli and $46 \%$ carried klebsiellae; in Hospital D, approximately $10 \%$ carried

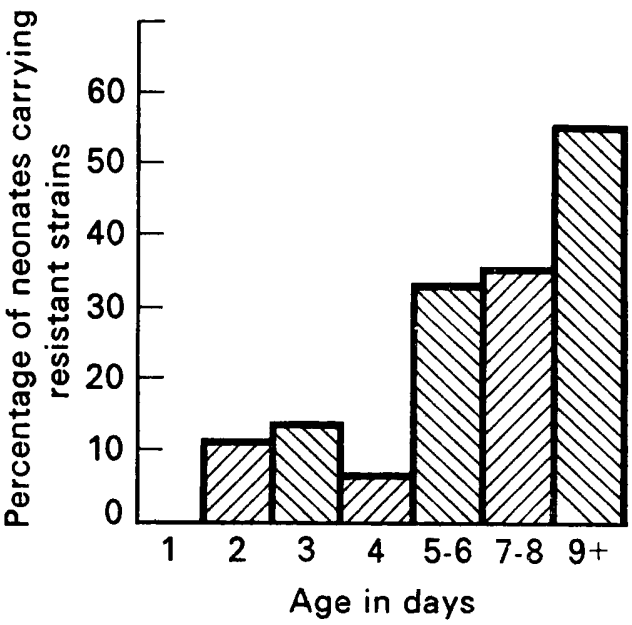

FIG. 1.-Acquisition of Escherichia coli by noenates in special care units.

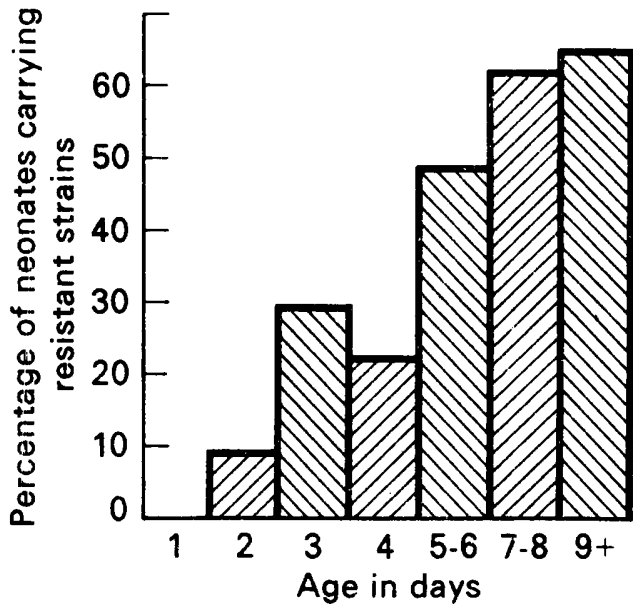

FIG. 3.-Acquisition of klebsiellae by neonates in special care units.

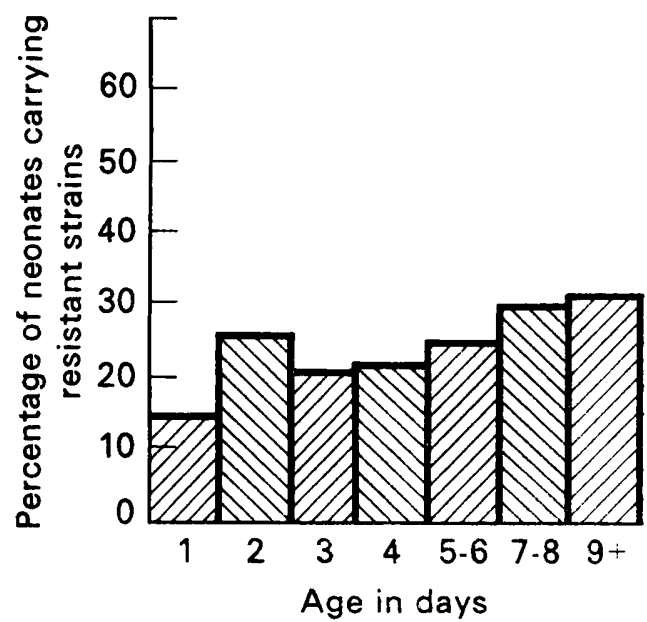

FIG. 2.-Acquisition of $E$. coli by neonates in ordinary wards.

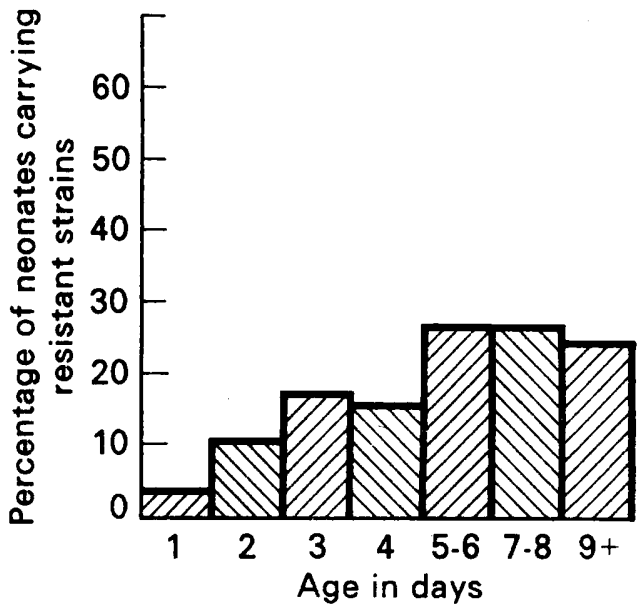

FIG. 4.-Acquisition of klebsiellae by neonates in ordinary wards.

antibiotic-resistant $E$. coli and only $4 \%$ carried klebsiellae. In Hospital B, 46 of the 116 babies sampled were in the Special Care Unit and the proportion of these carrying antibiotic-resistant $E$. coli was only $10 \%$.

\section{Antibiotic-resistance patterns}

The resistant strains of $E$. coli isolated in all four hospitals were mainly resistant to streptomycin, tetracycline, ampicillin and carbenicillin, and usually 
to sulphonamides (tables III and IV). Kanamycin resistance, although much less common, was noted particularly in Hospitals A and C, and chloramphenicol resistance in Hospital C. Among the klebsiellae examined, tetracycline resist-

\section{TABLE III}

Antibiotic-resistance patterns of $E$. coli isolated from neonatal faeces from four hospitals

\begin{tabular}{|c|c|c|c|c|c|c|c|c|c|c|c|c|c|c|}
\hline \multirow{2}{*}{ Hospital } & \multirow{2}{*}{$\begin{array}{l}\text { Number of } \\
\text { samples } \\
\text { taken }\end{array}$} & \multirow{2}{*}{$\begin{array}{l}\text { Number containing } \\
\text { resistant strains } \\
\text { of Klebsiella spp. } \\
\text { of } E \text {. coli }\end{array}$} & \multicolumn{12}{|c|}{ Number of $E$. coli isolates resistant to the stated agent* } \\
\hline & & & St & $\mathrm{T}$ & $\mathbf{A}$ & $\mathrm{C}$ & NA & NF & Col & $\mathbf{K}$ & Car & Cep & G & $\mathrm{Su}$ \\
\hline $\begin{array}{l}\text { A } \\
\mathbf{B} \\
\mathbf{C} \\
\mathbf{D}\end{array}$ & $\begin{array}{r}323 \\
116 \\
52 \\
397\end{array}$ & $\begin{array}{r}115 \\
11 \\
12 \\
41\end{array}$ & $\begin{array}{r}88 \\
6 \\
9 \\
15\end{array}$ & $\begin{array}{r}86 \\
8 \\
11 \\
22\end{array}$ & $\begin{array}{r}83 \\
5 \\
12 \\
14\end{array}$ & $\begin{array}{l}9 \\
2 \\
7 \\
5\end{array}$ & $\begin{array}{l}0 \\
0 \\
0 \\
0\end{array}$ & $\begin{array}{l}0 \\
0 \\
0 \\
0\end{array}$ & $\begin{array}{l}0 \\
0 \\
0 \\
0\end{array}$ & $\begin{array}{r}21 \\
1 \\
4 \\
0\end{array}$ & $\begin{array}{r}80 \\
4 \\
12 \\
12\end{array}$ & $\begin{array}{r}39 \\
1 \\
4 \\
0\end{array}$ & $\begin{array}{c}0 \\
0 \\
0 \\
\cdots\end{array}$ & $\begin{array}{r}57 \\
6 \\
9 \\
14\end{array}$ \\
\hline All & 888 & 179 & 118 & 127 & 114 & 23 & 0 & 0 & 0 & 26 & 108 & 44 & 0 & 86 \\
\hline
\end{tabular}

* St = streptomycin; $\mathrm{T}=$ tetracycline; $\mathrm{A}=$ ampicillin; $\mathrm{C}=$ chloramphenicol; $\mathrm{NA}=$ nalidixic acid; $\mathrm{NF}=$ nitrofurantoin; $\mathrm{Col}=$ colistin; $\mathrm{K}=$ kanamycin; $\mathrm{Car}=$ carbenicillin; $\mathrm{Cep}=$ cephaloridine; $\mathrm{G}=$ gentamicin; $\mathrm{Su}=$ sulphonamide.

TABLE IV

Antibiotic-resistance patterns of klebsiellae isolated from neonatal faeces from four hospitals

\begin{tabular}{|c|c|c|c|c|c|c|c|c|c|c|c|c|c|c|}
\hline \multirow{2}{*}{ Hospital } & \multirow{2}{*}{$\begin{array}{l}\text { Number of } \\
\text { samples } \\
\text { taken }\end{array}$} & \multirow{2}{*}{$\begin{array}{l}\text { Number containing } \\
\text { resistant strains } \\
\text { of Klebsiella spp. }\end{array}$} & \multicolumn{12}{|c|}{ Number of Klebsiella isolates resistant to the stated agent ${ }^{*}$} \\
\hline & & & St & $\mathbf{T}$ & A & $\mathrm{C}$ & NA & $\mathbf{N F}$ & Col & $\mathbf{K}$ & Car & Cep & G & Su \\
\hline $\begin{array}{l}\text { A } \\
\text { B } \\
\text { C } \\
\text { D }\end{array}$ & $\begin{array}{r}323 \\
116 \\
52 \\
397\end{array}$ & $\begin{array}{r}160 \\
46 \\
15 \\
15\end{array}$ & $\begin{array}{r}9 \\
2 \\
10 \\
1\end{array}$ & $\begin{array}{r}4 \\
10 \\
10 \\
1\end{array}$ & $\begin{array}{r}156 \\
44 \\
15 \\
14\end{array}$ & $\begin{array}{l}0 \\
1 \\
9 \\
0\end{array}$ & $\begin{array}{l}1 \\
0 \\
0 \\
0\end{array}$ & $\begin{array}{l}1 \\
1 \\
1 \\
0\end{array}$ & $\begin{array}{l}\mathbf{0} \\
\mathbf{0} \\
\mathbf{0} \\
\mathbf{0}\end{array}$ & $\begin{array}{l}0 \\
0 \\
1 \\
0\end{array}$ & $\begin{array}{r}139 \\
24 \\
13 \\
12\end{array}$ & $\begin{array}{r}53 \\
7 \\
6 \\
0\end{array}$ & $\begin{array}{c}\mathbf{0} \\
\mathbf{0} \\
\mathbf{0} \\
\ldots\end{array}$ & $\begin{array}{l}\ldots \\
\dddot{2} \\
\dddot{2}\end{array}$ \\
\hline All & 888 & 236 & 22 & 25 & 229 & 10 & 1 & 3 & 0 & 1 & 188 & 66 & 0 & 2 \\
\hline
\end{tabular}

* See footnote to table III.

ance was uncommon but most strains were resistant to ampicillin (and carbenicillin); strains in ordinary wards of Hospital $\mathrm{C}$ were also commonly resistant to chloramphenicol (7 of 23), and no gentamicin-resistant strains were isolated. Resistance to kanamycin was rare.

\section{Transferability of resistance}

Tables V and VI show the number of antibiotics to which the isolates of E. coli and Klebsiella spp. were resistant and the proportions of these in which transfer of resistance was demonstrated. Resistance was transferred in $49 \%$ 
of all E. coli strains tested, ranging from $18 \%$ of strains resistant to one antibiotic to $87 \%$ of strains resistant to five antibiotics. Transfer was demonstrated less often in strains resistant to six or seven antibiotics, possibly because these included 13 isolates from a group of samples from one special care unit all of

TABLE V

Antibiotic resistance and resistance transfer in $E$. coli

\begin{tabular}{l|ccc}
\hline \multicolumn{1}{c|}{$\begin{array}{c}\text { Organism } \\
\text { resistant to }\end{array}$} & \multicolumn{2}{|c}{ Number of isolates from } & $\begin{array}{c}\text { Number (and percentage) } \\
\text { of isolates in which } \\
\text { resistance was transferred }\end{array}$ \\
\hline One antibiotic & S.C.U. & wards & $7(18)$ \\
Two antibiotics & 15 & 25 & $9(32)$ \\
Three antibiotics & 8 & 21 & $14(48)$ \\
Four antibiotics & 25 & 9 & $26(76)$ \\
Five antibiotics & 25 & 5 & $26(87)$ \\
Six antibiotics & 14 & 1 & $6(40)$ \\
Seven antibiotics & 18 & 4 & $9(41)$ \\
\hline Any number of antibiotics & 111 & 87 & $97(49)$ \\
\hline
\end{tabular}

TABLE VI

Antibiotic resistance and resistance transfer in Klebsiella spp.

\begin{tabular}{|c|c|c|c|}
\hline \multirow{2}{*}{$\begin{array}{l}\text { Organism } \\
\text { resistant to }\end{array}$} & \multicolumn{2}{|c|}{ Number of isolates from } & \multirow{2}{*}{$\begin{array}{l}\text { Number (and percentage) } \\
\text { of isolates in which } \\
\text { resistance was transferred }\end{array}$} \\
\hline & $\mathrm{SCU}$ & wards & \\
\hline $\begin{array}{l}\text { One antibiotic } \\
\text { Two antibiotics } \\
\text { Three antibiotics } \\
\text { Four antibiotics } \\
\text { Five antibiotics } \\
\text { Six antibiotics }\end{array}$ & $\begin{array}{r}18 \\
82 \\
44 \\
2 \\
8 \\
6\end{array}$ & $\begin{array}{r}9 \\
59 \\
8 \\
4 \\
0 \\
0\end{array}$ & $\begin{array}{l}0 \\
1 \text { ( } \\
1(0 \cdot 7) \\
0 \\
0 \\
7(8) \\
6(100)\end{array}$ \\
\hline Any number of antibiotics & 160 & 80 & $15(6 \cdot 25)$ \\
\hline
\end{tabular}

which failed to transfer resistance. Transferable resistance was demonstrated much less frequently in klebsiellae $(6.25 \%)$ than in E. coli. Resistance to ampicillin, carbenicillin and often to cephaloridine is inherent in most klebsiellae, but this resistance was usually not transferable.

\section{Sources of resistant strains in babies' faeces}

Mothers. A comparison of organisms isolated from the faeces of 111 mothers and 93 babies in Hospital D is shown in table VII. In general, the proportions of mothers and babies colonised by different species are similar, except that klebsiellae were more commonly found in babies than in mothers. 
Of 55 paired mothers and babies, 21 neonates were colonised by strains not isolated from the mother and 14 neonates were colonised by strains apparently identical with the maternal strain in each case. In 27 pairs studied in Hospital A, the frequency of colonisation with resistant $E$. coli was $18.5 \%$ in babies and $48 \%$ in mothers, but the isolation of Klebsiella spp. was much higher in babies $(44 \%)$ than in mothers $(18.5 \%)$. In three cases unusual easily recognisable strains were present in mother and baby.

Environment. Klebsiella spp. and resistant $E$. coli were rarely isolated from the environment in Hospital A except from an occasional sink, soap-dish or

TABLE VII

Comparison of bacterial flora isolated from the faeces of 111 mothers and 93 babies in Hospital D

\begin{tabular}{|c|c|c|c|c|c|}
\hline \multirow[b]{2}{*}{$\begin{array}{l}\text { Category of the } \\
\text { organism isolated }\end{array}$} & \multicolumn{5}{|c|}{ Percentage number of mothers and babies colonised by } \\
\hline & E. coli & $\begin{array}{l}\text { Klebsiella } \\
\text { spp. }\end{array}$ & $\begin{array}{l}\text { Proteus } \\
\text { spp. }\end{array}$ & $\begin{array}{l}\text { Pseudomonas } \\
\text { aeruginosa }\end{array}$ & $\begin{array}{c}\text { Other Gram-negative } \\
\text { bacilli }\end{array}$ \\
\hline $\begin{array}{l}\text { Predominant strain in } \\
\text { mothers } \\
\text { babies }\end{array}$ & $\begin{array}{l}87 \\
72\end{array}$ & $\begin{array}{l}2 \\
5\end{array}$ & $\begin{array}{l}2 \\
1\end{array}$ & $\begin{array}{l}0 \\
1\end{array}$ & $\begin{array}{r}10 \\
5\end{array}$ \\
\hline $\begin{array}{l}\text { Isolated in large or } \\
\text { small numbers from } \\
\text { mothers } \\
\text { babies }\end{array}$ & $\begin{array}{l}96 \\
76\end{array}$ & $\begin{array}{r}8 \\
15\end{array}$ & $\begin{array}{l}6 \\
4\end{array}$ & $\begin{array}{l}2 \\
2\end{array}$ & $\begin{array}{l}22 \\
18\end{array}$ \\
\hline
\end{tabular}

drain. In the infant feeds examined klebsiellae were isolated in small numbers from 2 of 45 samples in Hospital A and none of 38 samples in Hospitals B and C.

\section{Cross-infection and length of stay}

The high incidence of Klebsiella spp in the faeces of babies and the rising carrier-rate of resistant $E$. coli and Klebsiella spp. with increasing length of stay in special care units, as shown in Figs. 1 and 2, suggest that cross-infection between babies was common. Table VIII shows the predominant bacteriocine patterns of Klebsiella spp. isolated from different wards in Hospital A. The endemic types in different wards of the same hospital often differed and varied over a period of months. The types endemic in individual hospitals differed from each other sometimes in antibiotic-resistance patterns and sometimes in bacteriocine patterns. On occasions when bacteriocine types in different hospitals were similar, serological types were usually different: e.g., a strain with the bacteriocine-typing pattern (4/7/24/27) found in Hospital A was of serological type 9 and a strain with the same pattern in Hospital B was of serological type 29. Isolation of an enteropathogenic strain of E. coli O86 was followed by a subclinical outbreak of cross-infection. A 12-day-old baby in the Special Care Unit of Hospital A was initially colonised by this strain. A month 
later, 7 of 26 babies had acquired this organism and all but one were in the ward for at least 17 days. Nearly 2 months later, 9 of 20 babies carried this strain and the average age of these babies was more than 14 days.

TABLE VIII

Predominant bacteriocine patterns of Klebsiella spp. in several wards and units of Hospital A

\begin{tabular}{|c|c|c|c|c|}
\hline $\begin{array}{c}\text { Ward or } \\
\text { unit }\end{array}$ & $\begin{array}{c}\text { Date of } \\
\text { isolation }\end{array}$ & Predominant pattern & $\begin{array}{l}\text { Number of } \\
\text { isolates showing } \\
\text { this pattern }\end{array}$ & $\begin{array}{c}\text { Number of isolates } \\
\text { tested }\end{array}$ \\
\hline SCU & $\begin{array}{r}1 \text { Dec. } 1970 \\
9 \text { Feb. } 1971 \\
22 \text { May } 1971 \\
27 \text { June } 1971\end{array}$ & $\begin{array}{l}27 \\
\mathrm{NT} \\
3 / 4 / 5 / 7 / 23 / 24 / 27 / 30 / 77 \\
3 / 4 / 5 / 7 / 23 / 24 / 27 / 30 / 77\end{array}$ & $\begin{array}{l}7 \\
9 \\
7 \\
5\end{array}$ & $\begin{array}{l}15 \\
13 \\
15 \\
14\end{array}$ \\
\hline $\begin{array}{l}\text { D6 } \\
\text { G2 } \\
\text { D5 }\end{array}$ & $\begin{array}{r}10 \text { Nov. } 1970 \\
27 \text { Oct. } 1970 \\
3 \text { Nov. } 1970\end{array}$ & $\begin{array}{l}4 / 5 / 7 / 24 / 27 \\
4 / 7 / 24 \\
4 / 7 / 24 / 27\end{array}$ & $\begin{array}{l}2 \\
2 \\
3\end{array}$ & $\begin{array}{l}2 \\
2 \\
6\end{array}$ \\
\hline
\end{tabular}

Factors affecting acquisition of resistant strains

Antibiotic therapy. Table IX shows the effect that the administration of antibiotics to mothers and babies had on their faecal colonisation with antibiotic-resistant organisms. The frequency of resistant $E$. coli and Klebsiella

TABLE IX

The effect of antibiotic administration on colonisation by Klebsiella spp. and E. coli in faeces of babies

\begin{tabular}{|c|c|c|c|}
\hline $\begin{array}{l}\text { Antibiotic } \\
\text { given to }\end{array}$ & $\begin{array}{l}\text { Number of } \\
\text { samples } \\
\text { tested }\end{array}$ & $\begin{array}{l}\text { Number (and percentage) } \\
\text { of samples yielding } \\
\text { Klebsiella spp. }\end{array}$ & $\begin{array}{l}\text { Number (and percentage) } \\
\text { of samples yielding } \\
\text { resistant } E \text {. coli }\end{array}$ \\
\hline \multirow{2}{*}{$\begin{array}{l}\text { Baby } \\
\text { Mother } \\
\text { Baby and } \\
\text { mother } \\
\text { Neither }\end{array}$} & $\begin{array}{l}69 \\
29\end{array}$ & $\begin{array}{l}52(75) \\
13(45)\end{array}$ & $\begin{array}{r}46(67) \\
8(28)\end{array}$ \\
\hline & $\begin{array}{r}19 \\
610\end{array}$ & $\begin{array}{r}17(89) \\
126(21)\end{array}$ & $\begin{array}{r}6(32) \\
97(16)\end{array}$ \\
\hline
\end{tabular}

spp. was significantly higher in the faeces of treated than of untreated babies $(P=<0.001)$. Antibiotics given to mothers alone did not have a significant effect on the babies' faecal flora. Of the 88 babies treated, only five were from ordinary wards and four of these babies carried Klebsiella spp. and only one carried resistant $E$. coli.

Type of delivery. Table $\mathrm{X}$ shows organisms isolated from babies in Hospital $D$ in relation to the type of delivery. It suggests that organisms other than E. coli were more likely to colonise infants after an abnormal than after a normal delivery. 
The type of delivery also affected the rapidity with which babies became colonised by Gram-negative bacilli. The babies most rapidly colonised were delivered with the aid of forceps (average $<2$ days); normal delivery was followed by colonisation after an average of $2 \frac{1}{2}$ days and Caesarean section by colonisation after an average of 5 days. Colonisation with antibiotic-resistant organisms occurred in $86 \%$ of the babies born by Caesarean section, but in only $40 \%$ of babies born normally or with forceps.

Detailed timings of events immediately before delivery were available for 58 of the babies studied in Hospital D. These data showed that the longer the delay between rupture of membranes and delivery, the more rapidly did faecal colonisation of the babies by Gram-negative bacilli occur. For example, in the case of those babies for whom the delay between membrane rupture and

TABLE X

The effect of the type of delivery on colonisation of neonates by Gram-negative bacilli

\begin{tabular}{|c|c|c|c|c|c|c|c|}
\hline \multirow[b]{2}{*}{$\begin{array}{l}\text { Type of } \\
\text { delivery }\end{array}$} & \multirow{2}{*}{$\begin{array}{l}\text { Number of } \\
\text { babies } \\
\text { sampled }\end{array}$} & \multicolumn{6}{|c|}{ Number of babies colonised by } \\
\hline & & $\begin{array}{c}\text { no } \\
\text { Gram-negative } \\
\text { bacilli }\end{array}$ & E. coli & $\begin{array}{l}\text { Klebsiella } \\
\text { spp. }\end{array}$ & $\begin{array}{l}\text { Proteus } \\
\text { spp. }\end{array}$ & $\begin{array}{c}P s . \\
\text { aeruginosa }\end{array}$ & $\begin{array}{c}\text { Other } \\
\text { Gram-negative } \\
\text { bacilli }\end{array}$ \\
\hline $\begin{array}{l}\text { Normal } \\
\text { Forceps } \\
\text { Caesarean }\end{array}$ & $\begin{array}{r}70 \\
16 \\
7\end{array}$ & $\begin{array}{l}9 \\
0 \\
0\end{array}$ & $\begin{array}{r}58 \\
11 \\
5\end{array}$ & $\begin{array}{l}7 \\
3 \\
3\end{array}$ & $\begin{array}{l}5 \\
0 \\
1\end{array}$ & $\begin{array}{l}0 \\
1 \\
1\end{array}$ & $\begin{array}{r}12 \\
5 \\
2\end{array}$ \\
\hline
\end{tabular}

delivery was 5 hours or less, colonisation did not occur until the 3rd day or later, whereas babies born after a delay of 10 hours or more between membrane rupture and delivery were colonised by Gram-negative bacilli in their faeces within 24 hours of birth.

\section{Discussion}

Antibiotic-resistant intestinal Gram-negative bacilli were rapidly acquired by neonates after birth. Carriage rates for Proteus spp. (7.5\%) and Ps. aeruginosa $(2 \cdot 2 \%)$ were low and the strains were probably acquired from mothers. Strains of $E$. coli and Klebsiella spp. were also probably initially acquired from mothers, as in the series reported by Bettelheim et al. (1974) who showed that 22 of 28 babies became colonised by a strain of $E$. coli identical with that isolated from the respective mother. However, in our studies we have shown that the isolation rate of antibiotic-resistant strains of $E$. coli and Klebsiella spp. increased in relation to the length of hospital stay and this suggests that other sources or factors were important. The carriage of Klebsiella spp. was much higher in special care units but the origin of these organisms was uncertain. Milk feeds were unlikely to be the major source, for if this were the case similar rates would be expected in special care units as in wards for normal babies receiving feeds from the same milk kitchen. Isolations of Klebsiella spp. from samples of milk were rare. A high carriage rate was also found in Hospital B where milk was 
terminally sterilised. Milk was also terminally sterilised in Hospital D, where the carriage rate of Klebsiella spp. was low (10\%). This figure corresponds with the findings of Dailey, Sturtevant and Feary (1972) who isolated resistant Klebsiella spp. from $13 \%$ of neonates.

Klebsiella spp. and other Gram-negative bacilli have been isolated in some units from solutions or equipment that might have constituted a single source, e.g., hexachlorophane soaps. Environmental studies in Hospital A rarely yielded Klebsiella spp. and as in most other investigations (Selden et al., 1971; Gardner and Smith, 1967) no common source was found. It is also possible that the intestinal tract of babies is particularly susceptible to colonisation with Klebsiella spp. (Pall, Milch and Szecsenyi-Nagy, 1969). The bacteriocine typing patterns suggest the presence of a rather diffuse and changing reservoir of endemic strains in these wards and units. Differences in the predominant type of Klebsiella spp. found, on the one hand in wards and on the other hand in special care units, have been shown by serotyping of Klebsiella spp. and enteropathogenic $E$. coli; distinct antibiotic-sensitivity patterns, involving bacterial resistance in special care units to kanamycin and in ordinary wards to chloramphenicol have also been shown. A kanamycin-resistant strain of E. coli 086 spread around the Special Care Unit of Hospital A unknown to the clinician, since there was no evidence of clinical infection. The main source of resistant Gram-negative bacilli in the nursery was probably babies' faeces, or possibly the upper respiratory tract which was not examined in this study, and the organisms were probably transmitted on the hands of staff members.

A number of factors were found to influence the rates of acquisition of these organisms. Length of stay in hospital and antibiotic treatment were obviously important, particularly in special care units. A significantly higher incidence of both Klebsiella spp. and of resistant E. coli was found in babies treated with antibiotics than in untreated babies or mothers. A similar selection of Klebsiella spp. has been observed in some published studies (e.g., Gardner and Smith, 1967; Selden et al., 1971) but not in others (Datta, 1969). Ampicillin and cloxacillin were the most frequent antibiotics given and ampicillin might be expected to select Klebsiella spp. (Price and Sleigh, 1970). Colonisation of the faeces with Gram-negative bacilli was more rapid when the mothers' membranes had been ruptured for long periods before delivery, presumably as a result of contamination of the amniotic fluid. Babies delivered by Caesarean section were colonised more slowly by sensitive strains than were normal babies, probably because they were not exposed to their mothers' vaginal-faecal flora; on the other hand, more of them subsequently acquired resistant strains, even in the absence of antibiotic treatment.

Many different antibiotic-sensitivity patterns were found among strains of $E$. coli, but strains resistant to ampicillin (and carbenicillin), tetracycline, streptomycin and often sulphonamide were common, and resistance to these agents was often transferable. This is a common pattern of transferable resistance in $E$. coli (Datta, 1969) and corresponds to the most frequently used antimicrobial agents (Ayliffe, 1973). As in other studies (e.g., Datta, 1971), $54 \%$ of 142 strains of $E$. coli resistant to tetracycline showed transferable 
resistance, in comparison with only $23 \%$ of 56 strains of $E$. coli resistant to drugs other than tetracycline. Most strains of Klebsiella spp. were resistant to ampicillin (and carbenicillin) and this resistance was rarely transferable; thus, only $6.25 \%$ of Klebsiella spp. transferred resistance, compared with $45.4 \%$ of resistant strains of E. coli. However, tetracycline resistance was transferred by $52 \%$ of 25 tetracycline-resistant strains of Klebsiella spp. The presence of transferable chloramphenicol resistance and the possible risk of transfer to Salmonella spp. has been referred to by Moorhouse and McKay (1968). Transferable chloramphenicol resistance was found in all four hospitals and was most common in Klebsiella spp. in Hospital C, although there is no record of chloramphenicol being used therapeutically in that hospital. The isolation of strains of $E$. coli with a similar antibiotic-sensitivity pattern, including resistance to chloramphenicol, suggested intergeneric transfer from Klebsiella spp. to Escherichia in the unit.

The possibility of transfer of resistance to enteropathogenic strains of $E$. coli is also of major importance and is one of the few instances in which transferable resistance is clinically relevant. Antibiotic treatment of infantile gastroenteritis, although not generally recommended, may be necessary in some severe infections. Highly resistant enteropathogenic strains may then fail to respond to treatment with conventional antibiotics, with possibly unfortunate results (e.g., Anderson, 1968a).

Antibiotic-resistant strains of Gram-negative bacilli are evidently acquired soon after birth, mainly from mothers, and are likely to be increased selectively if babies are treated with antibiotics. The frequency of carriage increases with length of stay in hospitals. Cross-infection is common between babies, particularly in special care units or in units for the care of premature babies.

\section{SUMMARY}

A total of 880 samples of faeces from 584 neonates in four hospitals were examined for the presence of antibiotic-resistant Gram-negative bacilli. The proportion of strains of Escherichia coli and Klebsiella spp. carrying R factors was also determined. Some resistant strains of $E$. coli and Klebsiella spp. were rapidly acquired after birth and the number of isolates increased in relation to the length of hospital stay. The proportion of isolates of Klebsiella spp. increased to over $60 \%$ in babies in special care units but increased to a lesser extent (less than $30 \%$ ) in other wards. The four hospitals showed differences in the proportion of babies carrying antibiotic-resistant strains and this was partly attributable to the inclusion of samples from special care units in three of the hospitals. Antibiotic-resistant Gram-negative bacilli other than E. coli and Klebsiella spp. were isolated much less frequently. Transferable resistance was demonstrated in $49 \%$ of 208 resistant strains of $E$. coli and in only $6.5 \%$ of 240 strains of Klebsiella spp.

An increased frequency of resistant strains was found in babies associated with abnormal deliveries and in babies treated with antibiotics. Resistant strains were probably acquired initially from the mothers, but although there 
was evidence of cross-infection with $E$. coli and Klebsiella spp. particularly in special care units, no common source was identified.

We wish to thank the staff of the four hospitals for providing the samples and Dr I. $\emptyset$ rskov for serological typing of Klebsiella strains.

\section{REFERENCES}

ANDERSON, E. S. 1965. Origin of transferable drug resistance factors in the Enterobacteriaceae. Br. med. J., $2,1289$.

ANDERSON, E. S. 1968a. Middlesborough outbreak of infantile enteritis and transferable drug resistance. Br. med. J., 1, 293.

ANDERSON, E. S. 1968b. Drug resistance in Salmonella typhimurium and its implications. Br. med. J., 3, 333.

AYLIFFe, G. A. J. 1973. In Current antibiotic therapy, edited by A. M. Geddes and J. D. Williams, Edinburgh and London, p. 53.

Ayliffe, G. A. J., Collins, B. J. ANd Petrit, F. A. 1970. Contamination of infant feeds in a Milton milk kitchen. Lancet, 1, 559.

Bettelheim, K. A., Breadon, A., Faitrs, M. C., O'Farrell, S. M. ANd Shooter, R. A. 1974. The origin of $\mathrm{O}$ serotypes of Escherichia coli in babies after normal delivery. J. Hyg., Camb., 72, 67.

Brown, V. I. AND LowbURY, E. J. L. 1965. Use of an improved cetrimide agar medium and other culture methods for Pseudomonas aeruginosa. J. clin. Path., 18, 752.

CowAN, S. F. AND SteEL, K. J. 1965. Manual for the identification of medical bacteria, London.

Dalley, K. M., Sturtevant, A. B. JR and Feary, T. W. 1972. Incidence of antibiotic resistance and $\mathrm{R}$ factors among Gram-negative bacteria isolated from the neonatal intestine. J. Pediat., 80, 198.

DATtA, N. 1969. Drug resistance and R factors in the bowel bacteria of London patients before and after admission to hospital. Br. med.J., 2, 407.

Datra, N. 1971. Prevalence of extrachromosomal drug resistance. $R$ factors in Escherichia coli. Ann. N.Y. Acad. Sci., 182, 59.

GARDNER, P. AND SMITH, D. H. 1969. Studies on the epidemiology of resistance (R) factors. i. Analysis of klebsiella isolates in a general hospital. ii. A prospective study of $\mathbf{R}$ factor transfer in the host. Ann. intern. Med., 71, 1.

HaLl, F. A. 1971. Bacteriocine typing of klebsiella species. J. clin. Path., 24, 712.

Linton, K. B., LeE, P. A., Richmond, M. H., Gillespie, W. A., Rowland, A. J. AND BaKeR, V. A. 1972. Antibiotic resistance and transmissible $R$ factors in the intestinal coliform flora of healthy adults and children in an urban and a rural community. J. Hyg., Camb., $70,99$.

MoORHOUSE, E. C. 1969. Transferable drug resistance in enterobacteria isolated from urban infants. Br. med. J., 2, 405.

Moorhouse, E. C. AND MCKAY, L. 1968. Hospital study of transferable resistance. $B r$. med. J., $2,741$.

Pall, G., Milch, H. and Szecsenyi-Nagy, S. 1969. Phage typing of klebsiella strains isolated from the faeces of infants and children. Acta. paediat. hung., 10, 265.

Price, D. J. E. AND SLeIGH, J. D. 1970. Control of infection due to Klebsiella aerogenes in a neurosurgical unit by withdrawal of all antibiotics. Lancet, 2, 1213.

Selden, R., Lee, S., WANG, W. L. L., Bennett, J. V. AND Eickhoff, T. C. 1971. Nosocomial klebsiella infections: intestinal colonisation as a reservoir. Ann. intern. Med., 74, 657.

Shooter, R. A., Cooke, E. M., Faiers, M. C., Breaden, A. L. and O'Farrell, S. M. 1971. Isolation of E. coli, Ps. aeruginosa and Klebsiella from food in hospitals, canteens and schools. Lancet, 2, 390. 